\title{
What makes a hospitality professional?
}

\section{Maria Gebbels}

\author{
Dr Maria Gebbels is a \\ programme leader for MA \\ International Tourism and \\ Hospitality Management at \\ the University of Greenwich, \\ UK. She was awarded a Ph.D. \\ for a study entitled, 'Career \\ Paths in Hospitality: A Life \\ History Approach' at the \\ University of Brighton, UK. \\ Her research interests are \\ career development studies, \\ critical hospitality studies and \\ gender issues. Besides her \\ work in academia, Maria was \\ employed for ten years in \\ various sectors of the \\ hospitality industry in \\ management roles.
}

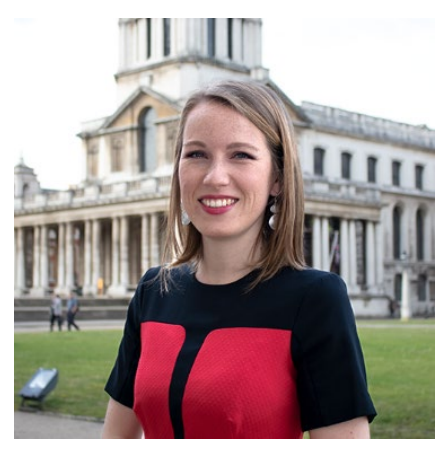

Despite the many efforts to propose effective career development solutions and career satisfaction in the hospitality industry, issues of staff retention and rising turnover continue to surface. The need for quality employees who consider hospitality a long-term career is of paramount importance. If employers wish to retain existing talent and also attract new talent, they have to know their employees' key characteristics. Until now the industry has preferred to recruit using competencies and task proficiency or specific technical expertise and job aptitude. Passion, sensitivity, team-oriented attitude, emotional self-control, and professional ethics have been identified as characteristics of professionalism within the hospitality industry. What remains unknown are the individual qualities that make a hospitality employee 'professional'.

To identify the new indicators of what constitutes a hospitality 'professional', an extensive review [1] of previous academic research was undertaken in these five areas: the hospitality environment [2, 3]; understanding professionalism [4]; self-efficacy (the power of believing in one's own capabilities) [5]; career inheritance (career as inherited from one's family) [6]; and career commitment (the emotional attachment to one's career) [7]. This resulted in identifying three common characteristics of a hospitality professional:

1. hospitality self-efficacy;

2. hospitality career commitment; and

3. hospitality career inheritance.

A hospitality professional has high levels of hospitality self-efficacy, which means having the confidence to achieve a particular task or an outcome; in this case, a successful hospitality career. A committed hospitality professional selfdirects their career path by taking charge of their career goals to improve their skills, career prospects and achieve promotions. Such an individual is also willing to learn and treats challenges as obstacles to be overcome, rather than as threats. Hospitality becomes an inherited part of their life and their career identity. This requires having the ability to thrive on the very nature of the industry, which is dynamic, exciting and ever-changing. The hospitality career inheritance is such a significant part of their life for hospitality professionals that it represents their ability to identify with hospitality beyond their working lives. This, in turn, is likely to compensate them for certain conditions of the job such as working long hours, but also to contribute to increased levels of hospitality career commitment. In times of increased changes in organisations, 
related to diversified workforce, globalisation and technological advancements, having a career is likely to have a positive influence on hospitality professionals who can exercise the most control over this part of their professional lives. In an industry known for its high staff turnover, a committed hospitality professional is an asset to both an organisation and the industry as a whole.

Knowledge of the key characteristics of a hospitality professional has implications for human resource management in the hospitality industry. Diversity of roles, being challenged and using their skills is what drives and motivates career-driven hospitality professionals to perform and develop an emotional attachment to their career. This requires, from the managers, a genuine understanding of the nature of hospitality, and what hospitality means to each professional. Together, the three professional characteristics are also considered a strong predictor of a person's desire to contribute to the successful performance of a hospitality business. Therefore, to meet the identified shortage of hospitality managers, the industry needs to attract hospitality professionals who are committed, emotionally attached to hospitality, and who exhibit high levels of self-confidence.

The research review on which this article was based can be read here https://doi.org/10.1386/hosp.9.2.215_1

\section{Corresponding author}

Maria Gebbels can be contacted at: m.m.gebbels@greenwich.ac.uk

\section{References}

(1) Gebbels, M.; Pantelidis, I. S.; Goss-Turner, S. Towards a Personology of a Hospitality Professional. Hospitality $\mathcal{E}$ Society 2019, 9 (2), 215-236. https://doi.org/10.1386/hosp.9.2.215_1

(2) Mooney, S. K.; Harris, C.; Ryan, I. Long Hospitality Careers - A Contradiction in Terms? International Journal of Contemporary Hospitality Management 2016, 28 (11), 25892608. https://doi.org/10.1108/IJCHM-04-2015-0206

(3) Cassel, S. H.; Thulemark, M.; Duncan, T. Career Paths and Mobility in the Swedish Hospitality Sector. Tourism Geographies 2018, 20 (1), 29-48. https://doi.org/10.1080/14616688.2017.1402946

(4) Cheng, S.; Wong, A. Professionalism: A Contemporary Interpretation in Hospitality Industry Context. International Journal of Hospitality Management 2015, 50 (1), 122-133. https://doi.org/10.1016/j.ijhm.2015.08.002

(5) Bandura, A. Social Foundations of Thought and Action: A Social Cognitive Theory; Prentice-Hall: Englewood Cliffs, NJ, 1986.

(6) Inkson, K. Images of Career: Nine Key Metaphors. Journal of Vocational Behavior 2004, 65 (1), 96-111. https://doi.org/10.1016/S0001-8791(03)00053-8

(7) Meyer, J. P.; Stanley, D. J.; Herscovitch, L.; Topolnytsky, L. Affective, Continuance, and Normative Commitment to the Organization: A Meta-analysis of Antecedents, Correlates, and Consequences, Journal of Vocational Behavior 2002, 61 (1), 20-52.

https://doi.org/10.1006/jvbe.2001.1842 